\title{
PENGARUH PEMBELAJARAN PENDEKATAN SAINTIFIK DAN VARIASI GAYA MENGAJAR TERHADAP MOTIVASI BELAJAR SISWA PADA PEMBELAJARAN PENDIDIKAN AGAMA ISLAM
}

\section{THE INFLUENCE OF SCIENTIFIC APPROACH LEARNING AND TEACHING STYLE VARIATIONS ON STUDENTS' LEARNING MOTIVATION IN ISLAMIC RELIGIOUS EDUCATION LEARNING}

\author{
Muhammad Lukman \\ Universitas Islam Negeri Sultan Syarif Kasim Riau, Indonesia \\ Email: muhammadlukman082@gmail.com \\ Risnawati \\ Universitas Islam Negeri Sultan Syarif Kasim Riau, Indonesia \\ Email: ewati04@gmail.com \\ Nurhasanah Bakhtiar \\ Universitas Islam Negeri Sultan Syarif Kasim Riau, Indonesia \\ Email: nurhasanah.bakhtiar@uin-suska.ac.id
}

\begin{abstract}
Abstrak
Penelitian ini bertujuan untuk menguji pengaruh pembelajaran pendekatan saintifik dan variasi gaya mengajar terhadap motivasi belajar siswa di SMP Negeri se-Kecamatan Marpoyan Damai, Kota Pekanbaru. Penelitian ini merupakan penelitian korelasional termasuk dalam pendekatan kuantitatif. Teknik pengambilan sampel dalam penelitian ini adalah random sampling. Analisis data menggunakan teknik regresi sederhana, regresi berganda dan koefisien determinasi (r2). Hasil analisis data menunjukkan bahwa pertama, terdapat pengaruh yang signifikan pembelajaran pendekatan saintifik terhadap motivasi belajar siswa pada SMP Negeri se-Kecamatan Marpoyan Damai, Kota Pekanbaru dengan tingkat pengaruh 0,279 dan nilai signifikansi 0,000 <0,05. Kedua, terdapat pengaruh yang signifikan variasi gaya belajar terhadap motivasi belajar siswa pada SMP Negeri se-Kecamatan Marpoyan Damai Kota Pekanbaru dengan tingkat pengaruh 0,226 dan nilai signifikansi 0,000 $<0,05$, dan terakhir terdapat pengaruh yang signifikan. pengaruh pembelajaran pendekatan saintifik dan variasi gaya mengajar terhadap motivasi belajar siswa dengan nilai signifikan $0,000<0,05$ dan persentase R2 ( $\mathrm{R}$ square) sebesar 0,090 atau (9\%). Hal ini menunjukkan bahwa persentase sumbangan variabel bebas (pembelajaran pendekatan saintifik dan variasi gaya mengajar) terhadap variabel terikat (motivasi belajar siswa) sebesar 9\% sedangkan sisanya (91\%) dipengaruhi oleh variabel lain.
\end{abstract}

Kata Kunci: pendekatan saintifik, variasi gaya mengajar, motivasi belajar 
Muhammad Lukman, Risnawati, Nurhasanah Bakhtiar: Pengaruh Pembelajaran Pendekatan Saintifik dan Variasi Gaya Mengajar terhadap Motivasi Belajar Siswa pada Pembelajaran Pendidikan Agama Islam

\begin{abstract}
This study aims to examine the influence of scientific approach learning and variation in teaching style on students'learning motivationat junior high schools in Marpoyan Damai District, Pekanbaru. This research was correlational research including in quantitative approach. This research used random sampling as the sampling technique. Data were analyzed by using simple regression, multiple regression and coefficient of determination $\left(r^{2}\right)$ techniques. The results of data analysis showed that firstly, there was a significant influence of scientific approach learning on students'learning motivation at state junior high schools in Marpoyan Damai District, Pekanbaru with a level of influence of 0.279 and the significant value of $0,000<0.05$, secondly, there was a significant influence of variation inteaching style on students 'learning motivation at state junior high schools in Marpoyan Damai District, Pekanbaru with a level of influence of 0.226 and the significant value of $0,000<0.05$, and lastly, there was a significant influence of scientific approach learning and variationin teaching style on students' learning motivation with a significant value of $0,000<0.05$ and the percentage of $R^{2}$ ( $R$ square) of 0.090 or (9\%). It shows that the percentage of contribution of independent variables (the learning of scientific approach and variation inteaching style) on the dependent variable (student motivation) was $9 \%$ meanwhile the remains (91\%) were influenced by other variables.
\end{abstract}

Keywords: scientific spproach, variation in teaching style, learning motivation

\title{
A. Pendahuluan
}

Motivasi belajar merupakan salah satu faktor yang menentukan keberhasilan siswa dalam kegiatan belajar, oleh karena itu siswa diharuskan memiliki motivasi belajar tersebut. Siswa yang memiliki motivasi belajar tinggi cenderung untuk selalu berusaha mencapai apa yang diinginkan walaupun mengalami hambatan dengan kesulitan dalam meraihnya. Motivasi dapat menentukan baik tidaknya dalam mencapai tujuan sehingga besarnya motivasi akan semakin besar kesuksesan belajarnya, siswa yang memiliki motivasi belajar adalah siswa yang giat berusaha, tampak gigih dengan tidak mau menyerah, giat membaca buku-buku untuk meningkatkan prestasinya dengan untuk memecahkan masalahnya, sebaliknya siswa yang motivasinya lemah tampak acuh tak acuh dengan mudah putus asa, perhatian tidak tertuju pada pelajaran, suka menganggu kelas, sehingga banyak mengalami kesulitan belajar.

Motivasi dianggap penting dalam upaya pembelajaran karena mendorong timbulnya tingkah laku dengan mempengaruhi serta mengubah tingkah laku siswa. Di 
Muhammad Lukman, Risnawati, Nurhasanah Bakhtiar: Pengaruh Pembelajaran Pendekatan Saintifik dan Variasi Gaya Mengajar terhadap Motivasi Belajar Siswa pada Pembelajaran Pendidikan Agama Islam

samping itu motivasi belajar memegang peranan penting dalam memberikan gairah atau semangat dalam belajar, sehingga siswa yang bermotivasi kuat memiliki energi banyak untuk melakukan kegiatan belajar dengan berdampak positif terhadap terpacapainya tujuan pembelajran. Sehubungan dengan pencapaian tujuan pembelajaran dengan pendidikan maka menumbuhkan motivasi belajar siswa menjadi tugas guru yang sangat penting. Pembelajaran akan berlangsung efektif apabila siswa memiliki motivasi dalam belajar. Oleh karena itu, motivasi belajar menjadi salah satu kunci keberhasilan dalam mencapai tujuan pembelajaran.

Menurut Syarif dalam Kusumah, motivasi memang bukan segala-galanya, tapi segala-galanya ditentukan oleh motivasi. Pernyataan tersebut mengandung arti bahwa motivasi memiliki peranan yang penting dalam kehidupan manusia. Motivasi memiliki jenis yang beragam, salah satunya adalah motivasi belajar. Motivasi belajar harus dimiliki oleh siswa sebagai dasar dalam melakukan kegiatan mereka yaitu belajar. Tidak ada siswa yang belajar tanpa adenganya motivasi. ${ }^{1}$

Motivasi ini berasal dari kata motif yaitu daya upaya yang mendorong seseorang untuk melakukan sesuatu. Dari arti ini munculah beberapa pendapat para ahli tentang arti motivasi. Di antaranya Sardiman mengatakan bahwa motivasi dapat diartikan daya penggerak yang telah menjadi aktif. ${ }^{2}$ Oemar Hamalik menegaskan juga bahwa motivasi adalah suatu perubahan energi dalam pribadi seseorang yang ditandai dengan timbulnya afektif dengan reaksi untuk mencapai tujuan. ${ }^{3}$ Lebih lanjut Ahmad Rohani mengatakan bahwa motivasi jikalau dikaitkan dengan belajar dapat diartikan usaha yang disadari oleh pihak guru untuk menimbulkan motif-motif pada diri peserta didik/pelajar yang menunjang kegiatan ke arah tujuan-tujuan belajar. ${ }^{4}$ Selanjutnya Hamzah B. Uno juga mengatakan bahwa motivasi belajar adalah dorongan internal dengan eksternal kepada siswa yang sedang belajar untuk mengadakan perubahan tingkah laku. ${ }^{5}$ Untuk itu motivasi dipandang penting bagi siswa.

Kata "motivasi" terambil dari kata "motiv" yang memiliki pengertian yaitu: daya penggerak yang bersemayam di dalam diri seseorang untuk melakukan pekerjaan-

\footnotetext{
2011), 28

${ }^{1}$ Indra Kusumah, Keajaiban Motivasi: Rahasia Sukses Sang Juara (Bandung: Salamadani, ${ }^{2}$ Sardiman, Interaksi dan Motivasi Belajar Mengajar (Jakarta: Rajawali Pers, 2016), 73

${ }^{3}$ Oemar Hamalik, Psikologi Belajar dan Mengajar (Bandung: Sinar Baru Algensindo 2004), 186

${ }^{4}$ Ahmad Rohani, Pengelolaan Pengajaran (Jakarta: Rineka Cipta, 2010), 12

${ }^{5}$ Hamzah B. Uno, Teori Motivasi dan Pengukurannya (Jakarta: Bumi Aksara, 2016), 23
} 
Muhammad Lukman, Risnawati, Nurhasanah Bakhtiar: Pengaruh Pembelajaran Pendekatan Saintifik dan Variasi Gaya Mengajar terhadap Motivasi Belajar Siswa pada Pembelajaran

Pendidikan Agama Islam

pekerjaan tertentu agar tercapai tujuan yang telah direncanakan dari awal. Jadi, motif tidak dapat dilihat dengan kasat mata, namun hal ini dapat diamati dan disimpulkan dari apa yang telah terjadi dan yang telah dilakukan oleh seseorang. Setiap aktivitas yang dilakukan oleh seseorang, hal ini didorong oleh keinginan dan kekuatan yang bersumber dari dalam diri. Kekuatan pendorong inilah yang disebut dengan motif. ${ }^{6}$

Rasulullah sebagai suri tauladan selalu memotivasi umatnya. Adapun contoh hadis yang menerangkan akan hal tersebut adalah hadis yang telah diriwayatkan oleh Abi Waqid al-Laitsi yang tertulis dalam Shahih al-Bukhary yang artinya: "Sesungguhnya pada suatu waktu Rasulullah sedang duduk di masjid kemudian datanglah tiga orang, yang dua orang tadi menghadap Rasulullah. Adapun yang satunya melihat tempat senggang dalam majelis itu, maka duduklah ia. Sedangkan orang kedua duduk di belakangnya, sedangkan orang ketiga pergi dan berpaling. Setelah itu Rasulullah bersabda: 'maukah kalian aku beritahukan kepadamu yang tiga orang tersebut? Adapun orang pertama adalah yang mencari keridhaan Allah, maka Allah ridha pula kepadanya, adapun orang kedua malu kepada Allah maka Allah pun malu kepadanya. Sedang yang satunya lagi ia berpaling (dari keridhaan Allah) maka Allah pun berpaling darinya." (H.R. Bukhori). ${ }^{7}$

Adapun hadis tersebut menjelaskan tentang salah satu keutamaan dari majelis ilmu dan memberikan semangat kepada orang agar mau terpikat dalam menuntut ilmu, dalam arti kata, bahwa hadis di atas juga memotivasi seseorang dalam menimba ilmu. Orang yang pertama, manusia yang datang ke dalam perkumpulan orang-orang yang menuntut ilmu, kamudian ia mencari tempat yang senggang dan kosong dan memiliki tekad agar selalu duduk di bagian terdepan, agar memperoleh infomasi dan transfer ilmu dengan jelas, tanpa ragu. Adapun yang kedua adalah manusia yang milih tempat duduk di bagian belakang, meskipun di depannya masih terdapat tempat yang kosong, namun dirinya tidak terdorong dan berkeinginan agar ia berada pada bagian terdepan tersebut. Dan yang ketiga adalah orang-orang yang melangkahkan kakinya jauh dan meninggalkan majelis ilmu, dalam artikata bahwa ia tidak memiliki motivasi dalam dirinya untuk menuntut ilmu dan menimba ilmu agar lebih banyak lagi. Perbedaan antara manusia atau murid yang memiliki motivasi tinggi adalah bahwa manusia yag

\footnotetext{
${ }^{6}$ Sumadi Suryabarata, Psikologi Pendidikan (Jakarta : Raja Grafindo Persada, 2004 ), 70

${ }^{7}$ Ibn Hajar al-'Asqalany, Fath al-Bari fi Shahih al-Bukhary, Juz I (Kairo: Dar al-Hadits, 1998), 
Muhammad Lukman, Risnawati, Nurhasanah Bakhtiar: Pengaruh Pembelajaran Pendekatan Saintifik dan Variasi Gaya Mengajar terhadap Motivasi Belajar Siswa pada Pembelajaran

Pendidikan Agama Islam

memiliki motivasi tinggi dalam belajar, ia akan selalu berusaha untuk mendapatkan ilmu dalam sebuah majelis tersebut, kemudian akan disenangi oleh guru karena kesungguhan yang terpancar dari dalam dirinya, kemudian ia akan memperoleh ilmu yang banyak sebagai buah dari kesungguhan yang telah ia lakukan dari awal.

Hal demikian adalah metode Rasulullah dalam memberikan motivasi dan penyemangat kepada para sahabat dalam menuntut ilmu dan mendapatkan kebaikan. Rasulullah SAW sangat menghargai dan mengagungkan manusia yang memiliki motivasi yang tinggi dalam menuntut ilmu an belajar, bahkan Rasulpun menyatakan bahwa majelis ilmu adalah sebagai riyadh al-jannah (taman surga), hal ini dilakukan oleh rasu agar memberikan semangat dan motivasi kepada para sahabat dalam mendatangi dan menuntut ilmu. ${ }^{8}$

Pandangan modern tentang proses pembelajaran menempatkan motivasi sebagai salah satu aspek penting. Guru harus mampu membangkitkan motivasi belajar siswa, agar siswa dapat berupaya mengarahkan segala kemampuan siswa dalam proses belajar. Masalah-masalah yang terjadi tersebut merupakan indikasi rendahnya motivasi siswa dalam belajar. Dalam memecahakan masalah tersebut salah satu inovasi yang dilakukan guru adalah dengan pembelajaran pendekatan saintifik. Pembelajaran ini melibatkan keterampilan proses, seperti mengamati, mengklasifikasi, mengukur, meramalkan, menjelaskan, dan menyimpulkan. Hal ini diyakini akan memperbaiki motivasi belajar siswa yang relatif rendah. Karena siswa memiliki keterlibatan lebih banyak dalam proses pembelajaran yang dilakukan guru.

Dalam pendekatan saintifik pelajaran dapat diperoleh dari berbagai media seperti, buku, internet, majala, koran, televisi, dan lain sebagainya. Oleh karena itu bentuk pembelajaran yang diharapkan adalah terciptanya dorongan kepada siswa. Materi pembelajaran yang dipelajari berasal dari sumber-sumber ilmu pngetahuan yang menuntut siswa untuk mengamati, mengklasifikasi, mengukur, meramalkan, menjelaskan, dan menyimpulkan, bukan hanya diberi tahu (transfer of knowladge). Jadi proses pembelajaran yang dilakukan dengan pendekatan saintifik yang dimaksud di sini adalah proses pembelajaran yang direncanakan dari awal dengan tujuan bahwa peserta didik menjadi aktif dalam menemukan konsep, hukum dengan jalan mengamati, merumuskan masalah, mengajukan atau mengelompokkan hipotesis, kemudian 2010), 64

${ }^{8}$ Syaiful Bahri Djamarah, Guru dan Anak Didik dalam Interaksi Edukatif (Jakarta: Rineka Cipta, 
Muhammad Lukman, Risnawati, Nurhasanah Bakhtiar: Pengaruh Pembelajaran Pendekatan Saintifik dan Variasi Gaya Mengajar terhadap Motivasi Belajar Siswa pada Pembelajaran Pendidikan Agama Islam

mengumpulkan data dengan barbagai cara, kemudian menganalisa data, mengambil kesimpulan, kemudian mengkomunikasikan konsep, hukum atau prinsip yang ditemukan.

Pendekatan saintifik adalah sebuah pendekatan pembelajaran menekankan pada aktifitas siswa melalui kegiatan mengamati, menannya, menalar, mencoba, mengumpulan dan menyimpulkan informasi pada kegiatan pembelajaran di sekolah. Pendekatan saintifik merupakan pendekatan pembelajaran yang memberikan kesempatan pada siswa secara luas untuk melakukan eksplorasi dan elaborasi materi yang dipelajari, di samping itu memberikan kesempatan pada peserta didik untuk mengaktualisasikan kemampuan melalui kegiatan pembelajaran yang dirancang oleh guru. ${ }^{9}$

Pendekatan saintifik (ilmiah) pada umumnya melibatkan kegiatan pengamat atau observasi yang dibutuhkan untuk perumusan hipotesis atau mengumpulkan data. Metode ilmiah pada umumnya dilandasi dengan pemaparan data yang diperoleh melalui pengamatan atau percobaan. Oleh sebab itu, kegiatan percobaan dapat diganti dengan kegiatan memperoleh informasi dari berbagai sumber. ${ }^{10}$ Pendekatan saintifik merupakan salah satu penekatan yang digunakan dalam kurikulum 2013 di sekolah, guru harus menggunakan pendekatan ilmiah (saintific). Karena pendekatan ini lebih efektif hasilnya dibandingkan pendekatan tradisional. ${ }^{11}$

Adapun ciri-ciri pendekatan saintifik adalah: (a) bahan pembelajaran diperoleh dari fakta atau penomena yang dapat dijelaskan dengan penalaran tertentu, logika, bukan dari khayalan, perkiraan yang tidak bisa dijelaskan dengan pasti; (b) proses belajar mengajar yang terjadi antara guru dan siswa tidak berlandaskan dari prasangka, namun lebih kepada berpikir secara logis dan masuk akal; (c) mengajak dan memotvasi siswa untuk berpikir secara kritis, analitis dan dalam mengelompokkan, memahami, menyelesaikan masalah dan menerapkan materi pembelajaran; (d) mengajak dan memotivasi siswa agar bisa berpikir secara hipotetik dalam menemukan perbedaan, persamaan, dan hubungan antara satu dengan lain antar materi pembelajaran; (e) mengajak dan memotivasi siswa agar bisa memahami, melaksanakan atau

\footnotetext{
${ }^{9}$ Rusman, Pemebelajaran Tematik Terpadu (Jakarta: PT. Raja Grafindo Persada, 2015), hlm. 232

${ }^{10}$ Ridwan Abdullah Sani, Pembelajaran Saintific untuk Implementasi Kurikulum 2013 (Jakarta: PT. Bumi Aksara, 2014), 51

${ }^{11}$ Shoimin Aris, 68 Model Pembelajaran Inovatif dalam Kurikulum 2013 (Yogyakarta: Arruz Media, 2014), 164
} 
Muhammad Lukman, Risnawati, Nurhasanah Bakhtiar: Pengaruh Pembelajaran Pendekatan Saintifik dan Variasi Gaya Mengajar terhadap Motivasi Belajar Siswa pada Pembelajaran

Pendidikan Agama Islam

mengaplikasikan pola pikir yang rasional dan tepat dalam menanggapi dalam proses belajar mengajar; (f) mengacu kepada konsep, teori, dan fakta empiris yang dapat dipertanggungjawabkan; dan (g) tujuan dalam proses belajar mengajar diberikan kepada peserta didik dengan sederhana dan jelas. ${ }^{12}$

Pembelajaran saintifik merupakan pembelajaran yang terpusat pada siswa, dimana siswa dituntut untuk menemukan sendiri materi yang berkaitan mata pelajaran tertentu. Pembelajaran dengan pendekatan saintifik memiliki karakteristik sebagai berikut: pertama, berpusat pada siswa, yang menggambarkan strategi-strategi pembelajaran, di mana guru lebih memfasilitasi dari pada harus mengajar langsung. Dalam pembelajaran yang berpusat pada siswa, guru secara sadar menempatkan perhatian yang lebih banyak pada keterlibatan, inisiatif, dan interaksi sosial siswa. Kedua, melibatkan keterampilan proses sains dalam mengonstruksi konsep, hukum atau prinsip. Mendorong dan menginspirasi peserta didik mampu berpikir hipotetik dalam melihat perbedaan, kesamaan, dan tautan satu sama lain dari subtansi atau materi pembelajaran. Mendorong dan menginspirasi perserta didik mampu memahami, menerapkan, dan mengembangkan pola berpikir yang rasional dan objektif dalam merespon subtansi atau materi pembelajaran. Ketiga, melibatkan proses-proses kognitif yang potensial dalam merangsang perkembangan intelek, khususnya keterampilan berpikir tingkat tinggi siswa. Mendorong dan menginspirasi peserta didik berpikir kritis, analisis, dan tepat dalam mengidentifikasi, memahami, memecahkan masalah, dan mengaplikasikan subtansi atau materi pembelajaran. Penjelasan guru, respon peserta didik, dan interaksi edukatif guru peserta didik terbatas dari prasangka yang serta merta, pemikiran subjektif, atau penalaran yang menyimpang dari alur berpikir logis. Keempat, dapat mengembangkan karakter peserta didik. Dengan pembelajaran saintifik diharapkan peserta didik akan mempunyai karakter yang kokoh, karena karakter ditanamkan melalui pembelajaran yang menekankan pada sikap spiritual dan sikap moral. Kelima, subtansi atau materi pembelajaran berbasis pada fakta atau fenomena yang dapat dijelaskan dengan logika atau penalaran tertentu, bukan sebatas kira-kira, khayalan, legenda, atau dongeng semata. Berbasis pada konsep, teori, dan

\footnotetext{
${ }^{12}$ Ibid.
} 
Muhammad Lukman, Risnawati, Nurhasanah Bakhtiar: Pengaruh Pembelajaran Pendekatan Saintifik dan Variasi Gaya Mengajar terhadap Motivasi Belajar Siswa pada Pembelajaran

Pendidikan Agama Islam

fakta empiris yang dapat dipertanggungjawabkan. Keenam, tujuan pembelajaran dirumuskan secara sederhana dan jelas, namun menarik sistem penyajian. ${ }^{13}$

Pendekatan saintifik mempunyai tujuan pembelajaran dan prinsip tertentu. Tujuan pembelajaran dengan pendekatan saintifik didasarkan pada keunggulan pendekatan tersebut. Beberapa tujuan pembelajaran dengan pendekatan saintifik adalah: (a) untuk meningkatkan kemampuan intelek, kususnya kemampuan berpikir tingkat tinggi siswa; (b) untuk membentuk kemampuan siswa dalam menyelesaikan suatu masalah secara sistematik; (c) tercipta kondisi pembelajaran di mana siswa merasa bahwa belajar itu merupakan suatu kebutuhan; (d) diperolehnya hasil belajar yang tinggi; (e) untuk melatih siswa dalam mengkomunikasikan ide-ide, khususnya dalam menulis artikel ilmiah; (f) untuk mengembangkan karakter siswa. ${ }^{14}$

Selain pendekatan saintifik ada faktor yang juga berperan dalam menumbuhkan motivasi siswa yaitu variabel variasi gaya mengajar guru, siswa akan termotivasi jika gaya mengajar gurunya yang dapat membuat suasana kelas menjadi riang, belajar tanpa beban dan hubungan kedekatan antara guru dan siswa serta siswa dengan siswa dapat terjalin erat.

Setiap guru masuk ke kelas selalu memunculkan variasi gaya mengajar, mulai dari variasi gerakan dan masuk dengan salam kehangatan atau memunculkan lelucon pada kesan pertama tatap muka. Dan yang tidak kalah pentingnya dengan komunikasi di dalam kelas, hubungan keeratan di luar kelas juga memberikan pengaruh terhadap keakraban antara guru dengan siswa. Sehingga ketika guru masuk ke kelas untuk mengajar, siswa tidak merasa ketakutan, malahan seperti sahabatnya yang lain.

Guru merupakan sosok yang setiap hari dilihat oleh siswa setiap belajar di sekolah. Materi yang berada di dalam buku refernsi dapat dipahami oleh siswa melalui guru dengan penjelasan guru di depan kelas. Guru adalah aktor yang memerankan tokoh dalam alur cerita dari bahan pelajaran yang ditetapkan oleh sekolah.

Ketika memberikan penjelasan, materi dihimpun dalam suatu pengertian yang sempit dan dijabarkan melalui contoh-contoh dalam kehidupan sehingga siswa merasa seperti berada dalam cerita tersebut. Yang penting dari mengajar adalah siswa dapat

\footnotetext{
${ }^{13}$ Muhammad Fathurrohman, Paradigma Pembelajaran Kurikulum 2013 Strategi Alternatif Pembelajaran di Era Global (Yogyakarta: Kalimedia, 2015), 115

${ }^{14}$ Tim Kemendikbud, Bahan Pengembangan Sumber Daya Manusia Pendidikan dan kebudayaan dan Penjaminan Mutu Pendidikan: Bahan Ajar Training of Trainer Implementasi Kurikulum 2013 (Jakarta: Kamendikbud, 2013), 3-4
} 
Muhammad Lukman, Risnawati, Nurhasanah Bakhtiar: Pengaruh Pembelajaran Pendekatan Saintifik dan Variasi Gaya Mengajar terhadap Motivasi Belajar Siswa pada Pembelajaran

Pendidikan Agama Islam

tertarik dan menaruh perhatian pada guru, penguasaan materinya ditentukan oleh siswa sendiri yaitu melalui pemberian tugas. Siswa lebih memahami materi jika diberikan tugas sehingga untuk mencari reward dari guru, dia harus berjuang mencari jawaban dan mengingat kembali apa yang telah dijelaskan oleh guru. Terkadang siswa juga sering memberikan pertanyaan.

Setiap guru mempunyai gaya tersendiri ketika megajar, siswa bisa meggambarkan dan menilai sosok gurunya seperti apa. Sehingga dengan guru yang begitu akrab dengan siswa, mereka sangat tertarik untuk mendengarkan dan melihat gaya gurunya yang membuat siswa tertawa karena penjelasan gurunya yang dapat membuat kelucuan.

Siswa juga termotivasi untuk belajar mata pelajaran Pendidikan Agama Islam (PAI), karena penyebab utamanya adalah sosok guru yang dengan mudah memberikan penjelasan yang membuat siswa dan sering. Dengan bekal yang cukup, guru dapat memuaskan dan memenuhi kebutuhan yang diperlukan oleh siswa, sehingga guru dapat memberikan apa yang dibutuhkan oleh peserta didik tersebut, begitu juga dengan memotivasi belajar, hal ini tidak menjadi beban bagi seorang guru, jika guru tersebut telah membekali dirinya dengan segudang ilmu dan pengalaman, sehingga dapat tercapai apa yang di inginkan, baik bagi peserta didik, guru ataupun sekolah.

Siswa yang termotivasi dalam pelajaran PAI dapat direalisasikan dengan cara suasana keriangan dan keingintahuan pada gejala sosial yang ada yang kemudian dipersembahkan pada suatu pernyataan pada gurunya. Pengerjaan tugas yang diberikan oleh guru selalu giat untuk mencari dan menelaah lebih dalam lagi melalui kegiatan diskusi yang digunakan guru untuk mencari titik terang dalam suatu masalah keagamaan. Motivasi siswa dapat dilihat ketika antusias siswa ingin mengikuti pelajaran PAI dan pada disiplinnya ketika memasuki kelas dan tertib ketika menunggu kedatangan guru masuk serta bertanya kepada guru yang lain disaat guru tersebut terlambat masuk.

Pendekatan saintifik ini dapat dilaksanakan dengan menggunakan gaya mengajar yang bervariasi. Di antara variasi gaya mengajar adalah variasi suara, pemusatan perhatian (focusing), pemberian waktu (pausing), kontak pandang, gerakan anggota badan (gesturing), perubahan posisi. Implementasi variasi gaya mengajar dalam pembelajaran guru sepatutnya peka terhadap berbagai situasi yang dihadapi sehingga 
Muhammad Lukman, Risnawati, Nurhasanah Bakhtiar: Pengaruh Pembelajaran Pendekatan Saintifik dan Variasi Gaya Mengajar terhadap Motivasi Belajar Siswa pada Pembelajaran

Pendidikan Agama Islam

dapat menyesuaikan pola tingkah lakunya dalam mengajar dengan situasi yang ada. Dianne Lapp, dan kawan-kawan dalam Ali, menanamkan pola umum tingkah laku mengajar yang dimiliki guru dengan istilah "gaya mengajar atau teaching style."15

Gaya mengajar bertujuan untuk menimbulkan motivasi belajar siswa. Menurut Wina Sanjaya, bahwa proses pembelajaran motivasi merupakan salah satu aspek dinamis yang sangat penting. Sering terjadi siswa yang kurang berprestasi bukan disebabkan oleh kemampuannya yang kurang, akan tetapi dikarenakan tidak adanya motivasi untuk belajar sehingga ia tidak berusaha untuk mengusahakan segala kemampuannya. $^{16}$ Dalam proses pembelajaran tradisional yang menggunakan pendekatan ekspositor (penyampaian materi secara verbal/ceramah) kadang-kadang unsur terlupakan oleh guru. Guru seakan-akan memaksakan siswa menerima materi yang disampaikannya. Keadaan ini tidak menguntungkan karena siswa tidak dapat belajar dengan optimal yang tentunya pencapaian hasil belajar juga tidak optimal.

Berdasarkan uraian tersebut berikut penulis cantumkan beberapa jurnal terkait dengan variabel penelitian. Pertama, Sadriani dan kawan-kawan menulis tentang pengaruh pendekatan saintifik terhadap motivasi belajar sains pada siswa kelas IV SD Inpres 1 Sidondo. Hasil penelitian menunjukkan bahwa pembelajaran pendekatan saintifik berpengaruh terhadap peningkatan motivasi belajar sains siswa. Hal ini diketahui dari hasil perhitungan berdasarkan gainscore normalized dengan perolehan 0,33 atau dikategorikan mengalami peningkatan sedang. Selain itu, melalui pendekatan saintifik dapat diketahui aktivitas guru dan siswa dikategorikan baik, kemampuan kognitif ratarata mencapai KKM dan sikap siswa membudaya. Hasil penilaian tentang motivasi siswa didukung oleh hasil wawancara siswa yang memberikan pernyataanpernyataan positif tentang efektifitas pendekatan saintifik dalam pembelajaran. ${ }^{17}$

Kedua, I Nyoman Sumayasa dan kawan-kawan meneliti tentang pengaruh implementasi pendekatan saintifik terhadap motivasi belajar dan hasil belajar Bahasa Indonesia pada siswa kelas VI di Sekolah Dasar Se-Gugus VI Kecamatan Abang, Karangasem. Berdasarkan hasil penelitian dapat dijelaskan bahwa terdapat pengaruh

\footnotetext{
${ }^{15}$ Muhammad Ali, Guru dalam Proses Belajar Mengajar (Bandung: Penerbit Sinar Baru Algensindo, 2010), 5

${ }^{16}$ Wina Sanjaya, Strategi Pembelajaran: Berorientasi Standar Proses Pendidikan (Jakarta: Kencana Prenada Media, 2010), 249

${ }^{17}$ Sadriani, Amram Rede, I Wayan Darmadi, "Pengaruh Pendekatan Saintifik terhadap Motivasi Belajar Sains pada Siswa Kelas IV SD Inpres 1 Sidondo,” Jurnal Kreatif Online, Vol. 6, No. 3 (2018): $163-173$
} 
Muhammad Lukman, Risnawati, Nurhasanah Bakhtiar: Pengaruh Pembelajaran Pendekatan Saintifik dan Variasi Gaya Mengajar terhadap Motivasi Belajar Siswa pada Pembelajaran Pendidikan Agama Islam

motivasi belajar bahasa Indonesia antara siswa yang mengikuti pelajaran dengan pendekatan saintifik dan siswa yang belajar dengan model pembelajaran konvensional pada siswa kelas VI Gugus VI Kecamatan Abang, Karangasem. Pertama, motivasi belajar siswa yang mengikuti model pembelajaran saintifik (kelompok eksperimen) hasilnya lebih baik daripada motivasi belajar siswa yang mengikuti model pembelajaran konvensional (kelompok kontrol). Kedua, hasil belajar siswa yang mengikuti model pembelajaran saintifik (kelompok eksperimen) hasilnya lebih baik daripada hasil belajar siswa yang mengikuti model pembelajaran konvensional (kelompok kontrol). Ketiga, motivasi dan hasil belajar siswa yang mengikuti model pembelajaran saintifik (kelompok eksperimen) hasilnya lebih baik daripada motivasi dan hasil belajar siswa yang mengikuti model pembelajaran konvensional (kelompok kontrol). ${ }^{18}$

Ketiga, Vialinda Siswati menulis tentang pengaruh pembelajaran dengan pendekatan saintifik terhadap prestasi belajar pada siswa kelas VII SMP Negeri 1 Wringinanom Gresik. Dari analisis tersebut diketahui bahwa pendekatan saintifik terhadap pembelajaran berpengaruh terhadap motivasi berprestasi pada siswa kelas VII SMP Negeri 1 Gresik Wringinanom diperoleh nilai Fhitung 15641 (signifikansi $\mathrm{F}=$ 0,000 ). Jadi Fhitung $>$ Ftabel $(15641>1,60)$ atau Sig F $<5 \%(0,000<0,05)$. Artinya pembelajaran dengan pendekatan saintifik berpengaruh terhadap motivasi berprestasi pada siswa kelas VII SMP Negeri 1 Gresik Wringinanom. Maka hipotesis nol $\left(\mathrm{H}_{0}\right)$ ditolak dan hipotesis kerja $\left(\mathrm{H}_{1}\right)$ diterima. ${ }^{19}$

Keempat, As'ad Furqon Syadzili dan kawan-kawan meneliti tentang pengaruh pendekatan scientific terhadap motivasi dan hasil belajar Fisika siswa kelas XI SMA Negeri 1 Kopang. Hasil penelitian ini menunjukkan bahwa ada pengaruh pendekatan scientific terhadap motivasi dan hasil belajar Fisika siswa kelas XI SMA Negeri 1 Kopang. Jenis penelitian ini merupakan penelitian eksperimen. Desain penelitian menggunakan pretest dan posttest one group design, dengan populasi seluruh siswa kelas XI IPA SMA Negeri 1 Kopang. Sampel penelitian terdiri dari dua kelas yaitu kelas XI IPA 1 sebagai kelas eksperimen dan kelas XI IPA 2 sebagai kelas kontrol yang

\footnotetext{
${ }^{18}$ I Nyoman Sumayasa, A.A.I.N. Marhaeni, Nyoman Dantes, "Pengaruh Implementasi Pendekatan Saintifik terhadap Motivasi Belajar dan Hasil Belajar Bahasa Indonesia pada Siswa Kelas VI di Sekolah Dasar Se-Gugus VI Kecamatan Abang, Karangasem," e-Journal Program Pascasarjana Universitas Pendidikan Ganesha Program Studi Pendidikan Dasar, Vol. 5 (2015): 1-11

${ }^{19}$ Vialinda Siswati, "Pengaruh Pembelajaran dengan Pendekatan Saintifik terhadap Motivasi dan Prestasi Belajar Mata Pelajaran Pendidikan Agama Islam pada Kelas VII SMP Negeri 1 Wringinanom Gresik," Progressa: Journal of Islamic Religious Instruction, Vol. 1, No. 1 (2017): 1-12
} 
Muhammad Lukman, Risnawati, Nurhasanah Bakhtiar: Pengaruh Pembelajaran Pendekatan Saintifik dan Variasi Gaya Mengajar terhadap Motivasi Belajar Siswa pada Pembelajaran Pendidikan Agama Islam

diambil dengan menggunakan teknik random sampling. Rata-rata nilai pretest kelas eksperimen dan kelas kontrol berturut-turut 23,21 dan 30,15 dan nilai posttest kelas eksperimen dan kontrol berturut-turut 74,74 dan 57,68. Sedangkan untuk motivasi belajar siswa mengalami peningkatan. Persentase nilai tes awal kelas eksperimen dan kelas kontrol berturut-turut 59,85 \% (rendah) dan 64,65 \% (cukup) meningkat menjadi $82,40 \%$ (tinggi) dan 76,56 \% (cukup) pada tes akhir. Uji homogenitas dan normalitas data motivasi dan hasil belajar Fisika siswa menunjukkan bahwa data terdistribusi normal dan kedua data homogen. Data ini kemudian dianalisis menggunakan uji-t dan diperoleh thitung untuk motivasi dan hasil belajar berturut-turut 3,89 dan 5,47 dengan ttabel 1,99, pada taraf signifikan $5 \%$ dengan thitung $>$ tabel. $^{20}$

Kelima, Zulfia Muslimawati dan kawan-kawan menulis tentang pembelajaran pendekatan saintifik melalui model problem solving untuk meningkatkan motivasi belajar dan hasil belajar Fisika di kelas X IPA.1 SMAN 9 Kota Bengkulu. Berdasarkan hasil penelitian dapat disimpulkan bahwa pembelajaran pendekatan saintifik melalui model problem solving dapat meningkatkan aktivitas belajar siswa, motivasi belajar siswa dan hasil belajar siswa. Hasil angket motivasi belajar siswa pada siklus I dengan rata-rata skor sebesar 44,48 dalam kategori sedang, siklus II sebesar 51,74 dalam kategori sedang, siklus III sebesar 57,31 dalam kategori tinggi, siklus IV sebesar 63,86 dalam kategori tinggi. Hasil belajar siswa aspek pengetahuan pada siklus I diperoleh daya serap sebesar 70,86\% dan ketuntasan belajar sebesar 37,93\% (belum tuntas), siklus II diperoleh daya serap sebesar 76,72\% dan ketuntasan belajar sebesar 79,31\% (tuntas), siklus III diperoleh daya serap sebesar $82,24 \%$ dan ketuntasan belajar sebesar $89,66 \%$ (tuntas) dan siklus IV diperoleh daya serap sebesar 93,97\% dan ketuntasan belajar sebesar $100 \%$ (tuntas). $^{21}$

Penelitian dan tulisan relevan tersebut membuktikan ada hubungan keterkaitan antara masing-masing variabel. Belum ada penelitian yang menggarap tentang pengaruh pembelajaran pendekatan saintifik dan variasi gaya mengajar terhadap motivasi belajar

${ }^{20}$ As'ad Furqon Syadzili, Sukainil Ahzan, Dwi Pangga, "Pengaruh Pendekatan Scientific terhadap Motivasi dan Hasil Belajar Fisika Siswa," Jurnal Ilmiah Pendidikan Fisika Lensa, Vol. 3, No.1 (2015): 244

${ }^{21}$ Zulfia Muslimawati, Rosane Medriati, Eko Risdianto, "Penerapan Pendekatan Saintifik Melalui Model Problem Solving untuk Meningkatkan Motivasi Belajar dan Hasil Belajar Fisika di Kelas X IPA.1 SMAN 9 Kota Bengkulu,” Jurnal Pembelajaran Fisika, Vol. 1, No. 1 (2017): 114 
Muhammad Lukman, Risnawati, Nurhasanah Bakhtiar: Pengaruh Pembelajaran Pendekatan Saintifik dan Variasi Gaya Mengajar terhadap Motivasi Belajar Siswa pada Pembelajaran

Pendidikan Agama Islam

siswa pada mata pelajaran Pendidikan Agama Islam di SMP Negeri Se-Kecamatan Marpoyan Damai Kota Pekanbaru.

Berdasarkan hasil observasi dan diskusi dengan guru-guru mata pelajaran Pendidikan Agama Islam, pembelajaran Pendidikan Agama Islam di SMP Negeri seKecamatan Marpoyan Damai Kota Pekanbaru menunjukkan indikasi adanya gejalagejala yang muncul, di antaranya: ${ }^{22}$ (a) siswa lebih sering diam dalam proses pembelajaran; (b) siswa melempar teman pake gulungan kertas saat pembelajaran; (c) siswa lesu dalam pembelajaran; (d) siswa sering melirik ke luar kelas; (e) siswa sering keluar masuk pada saat proses pembelajaran; (f) siswa sering menguap pada proses pembelajaran; (g) siswa sering menggaruk kepala; (h) siswa melukis/ menggambar di buku pelajarannya yang tidak ada kaitannya dengan mata pelajaran PAI; dan (i) kurangnya keterlibatan siswa secara aktif dalam proses pembelajaran secara keseluruhan.

\section{B. Metode}

\section{Jenis Penelitian}

Jenis penelitian yang digunakan dalam penelitian ini adalah penelitian lapangan (field research) dengan metode expost facto serta menggunakan pendekatan korelasi atau hubungan (correlation research), artinya peneliti tidak menggunakan perlakuan terhadap variabel-variabel penelitian, melainkan mengkaji fakta-fakta yang telah terjadi berdasarkan pemahaman responden penelitian.

Penelitian hubungan atau korelasi dilakukan untuk mengetahui ada atau tidaknya dan seberapa besar ditemukannya hubungan antara dua variabel atau lebih secara kuantitatif untuk menganalisa pengaruh antara dua variabel bebas (independent variabel) yaitu pembelajaran pendekatan saintific $\left(\mathrm{X}_{1}\right)$, dan gaya mengajar $\left(\mathrm{X}_{2}\right)$, dengan satu variabel terikat (dependent variabel) yaitu motivasi belajar siswa (Y).

\section{Waktu dan Tempat Penelitian}

Penelitian ini dilaksanakan pada tanggal 2 Maret 2020 sampai dengan tanggal 4 Mei 2020, yang bertempat di SMP Negeri se-Kecamatan Marpoyan Damai Kota Pekanbaru, yakni SMP Negeri 25 dan SMP Negeri 34 Pekanbaru. Dipilihnya SMP Negeri se-Kecamatan Marpoyan Damai Kota Pekanbaru sebagai tempat penelitian $10.00 \mathrm{Wib}$

${ }^{22}$ Hasil Wawancara dengan guru Agama Islam di SMPN 34 Pekanbaru, tgl 24 Juli 2019 jam 
Muhammad Lukman, Risnawati, Nurhasanah Bakhtiar: Pengaruh Pembelajaran Pendekatan Saintifik dan Variasi Gaya Mengajar terhadap Motivasi Belajar Siswa pada Pembelajaran Pendidikan Agama Islam

karena masalah yang diteliti ada di tempat ini dan terjangkau oleh penulis untuk melakukan penelitian.

\section{Subjek dan Objek Penelitian}

Subjek dalam penelitian ini adalah guru mata pelajaran Pendidikan Agama Islam dan siswa di SMP Negeri se-Kecamatan Marpoyan Damai Kota Pekanbaru. Sedangkan yang menjadi objek dalam penelitian ini adalah pengaruh pembelajaran pendekatan saintifik dan gaya mengajar guru pada mata pelajaran Pendidikan Agama Islam di SMP Negeri se-Kecamatan Marpoyan Damai Kota Pekanbaru.

\section{Populasi dan Sampel}

Populasi adalah wilayah generalisasi yang terdiri atas objek/subjek yang mempunyai kualitas dan karakteristik tertentu yang ditetapkan oleh peneliti untuk dipelajari dan kemudian ditarik kesimpulannya. ${ }^{23}$ Adapun yang menjadi populasi dalam penelitian ini adalah seluruh siswa SMP Negeri se-Kecematan Marpoyan Damai Kota Pekanbaru yang berjumlah 4.164.

Tabel 1. Jumlah Populasi Penelitian

\begin{tabular}{ccc}
\hline No & Nama Sekolah & Populasi \\
\hline 1 & SMP Negeri 25 Pekanbaru & 1054 \\
2 & SMP Negeri 34 Pekanbaru & 780 \\
\hline \multicolumn{2}{c}{ Jumlah } & 1.834 \\
\hline
\end{tabular}

Dalam penelitian ini, penulis mengambil sampel menggunakan rumus slovin dengan jumlah sampel yaitu 330 orang. Berikut data tentang penarikan sampel dengan rumus slovin:

$$
\begin{aligned}
& \mathrm{n}=\mathrm{N} /\left(1+\left(\mathrm{N} \mathrm{x} \mathrm{e}^{2}\right)\right) \\
& \text { Sehingga: } \mathrm{n}=/\left(1+\left(1.834 \times 0,05^{2}\right)\right) \\
& \mathrm{n}=1.834 /(1+(1.834 \times 0,0025)) \\
& \mathrm{n}=1.834 /(1+4,6 \\
& \mathrm{n}=330 / 5,6 \\
& \mathrm{n}=330
\end{aligned}
$$

\footnotetext{
${ }^{23}$ Sugiyono, Metode Penelitian Pendidikan (Pendekatan Kuantitatif, Kualitatif, dan R\&D) (Bandung: Alfabeta, 2014), 117
} 
Muhammad Lukman, Risnawati, Nurhasanah Bakhtiar: Pengaruh Pembelajaran Pendekatan Saintifik dan Variasi Gaya Mengajar terhadap Motivasi Belajar Siswa pada Pembelajaran Pendidikan Agama Islam

\section{Teknik Pengumpulan Data}

a. Angket (Kuiseoner)

Dalam penelitian ini angket ditujukan kepada siswa untuk mendapatkan data pokok tentang pembelajaran pendekatan saintifik (X1), variasi gaya mengajar (X2), dan motivasi belajar siswa (Y). Angket disusun menggunakan skala interval dengan lima opsi, yakni: selalu, sering, kadang-kadang, jarang, dan tidak pernah. Angket peneltian ini disebarkan via daring dengan menggunakan aplikasi Whatshap, di mana angket dikirim kepada guru Pendidikan Agama Islam pada setiap sekolah, di SMP Negeri 25 dengan Hariadi, S.Ag. dan SMP Negeri 34 dengan Kasmawati, M.Pd. Angket tersebut diteruskan kepada siswa-siswi yang berada di sekolah tersebut yang telah bergabaung dalam group penelitian. Kemudian angket tersebut dikirim kembali oleh siswa setelah diisi ke dalam group penelitian yang nantinya menjadi bukti pengambilan data bagi peneliti.

\section{b. Dokumentasi}

Dokumentasi adalah catatan peristiwa yang sudah berlalu bisa berbentuk tulisan, gambar, atau karya-karya monumental dari seseorang. ${ }^{24}$ Teknik ini digunakan untuk memperoleh data yang berhubungan dengan penelitian seperti profil SMP Negeri seKecamatan Marpoyan Damai Kota Pekanbaru, Rencana Pelaksanaan Pembelajaran (RPP), jadwal mengajar guru, serta dokumentasi penelitian.

\section{Teknik Analisis Data}

Teknik analisis data dalam penelitian ini mengunakan teknis analisis data regresi sederhana dan regresi berganda dengan bantuan SPSS. Fakta digali dengan menggunakan angket yang berisi sejumlah pertanyaan yang merefleksikan persepsi responden (peserta didik) terhadap pembelajaran pendekatan saintifik, gaya mengajar guru PAI dan motivasi belajar siswa di SMP Negeri se-Kecamatan Marpoyan Damai Kota Pekanbaru. Melalui pendekatan ini diharapkan data yang diperoleh dapat diubah dalam bentuk angka dan analisis statistik menggunakan rumus korelasional.

a. Uji Prasyarat Penelitian

Uji prasyarat penelitian terdiri dari uji normalitas, uji linieritas, dan uji multikolonialitas.

\footnotetext{
${ }^{24}$ Ibid., 329
} 
Muhammad Lukman, Risnawati, Nurhasanah Bakhtiar: Pengaruh Pembelajaran Pendekatan Saintifik dan Variasi Gaya Mengajar terhadap Motivasi Belajar Siswa pada Pembelajaran Pendidikan Agama Islam

b. Uji Hipotesis

1) Uji regresi berganda

Analisis regresi berganda bertujuan untuk meramalkan nilai pengaruh dua atau lebih variabel prediktor terhadap satu variabel kriterium dengan mengunakan persamaan regresi, yaitu: $\mathrm{Y}=\mathrm{a}+\mathrm{b} 1 \mathrm{XI}+\mathrm{B} 2 \mathrm{X} 2$

Keterangan:

$\mathrm{Y}=$ nilai yang diprediksi

$\mathrm{X}=$ nilai variabel prediktor

$\mathrm{a}=$ bilangan konstan

$\mathrm{b}=$ bilangan koefisien prediktor

\section{1) Koefisien Determinasi $R 2$}

Kofisien determinasi (R2) digunakan untuk mengetahui besarnya kontribusi variabel independen dalam hal ini adalah pembelajaran remedial dan pengayaan dengan hasil belajar. Koefesien ini disebut koefisien penentu. Karena varians yang terjadi pada variabel dependen dapat dijelaskan melalui varians yang terjadi pada variabel independen, dengan bantuan program SPSS versi 17.

\section{Hasil Penelitian dan Pembahasan}

Data dalam penelitian dilakukan uji asumsi klasik yang terdiri dari uji normalitas, uji linearitas dan uji uji multikolinieritas:

\section{Uji Normalitas}

Pada penelitian ini, pengujian normalitas data dapat dilihat dari normal probability plot. Pengambilan keputusan dalam uji normalitas menggunakan analisis grafik ini didasarkan pada: jika data menyebar di sekitar garis diagonal dan mengikuti garis diagonal, maka model regresi memenuhi asumsi normalitas. Jika data menyebar jauh dari diagonal dan atau tidak mengikuti arah garis diagonal, maka model regresi tidak memenuhi asumsi normalitas.

Tabel 2. Hasil Uji Normalitas Data

\begin{tabular}{lcccc}
\hline \multicolumn{1}{c}{ Data } & $\begin{array}{c}\text { Kolmogorov } \\
\text { Smirnov }\end{array}$ & $\begin{array}{c}\text { Sig. (2- } \\
\text { tailed) }\end{array}$ & A & Keterangan \\
\hline Pendekatan Pembelajaran Saintifik & 1.293 & 0,07 & 0,05 & Normal \\
Variasi Gaya Mengajar & 1.100 & 0,178 & 0,05 & Normal \\
Motivasi Siswa & 1,325 & 0,06 & 0,05 & Normal \\
\hline
\end{tabular}


Muhammad Lukman, Risnawati, Nurhasanah Bakhtiar: Pengaruh Pembelajaran Pendekatan Saintifik dan Variasi Gaya Mengajar terhadap Motivasi Belajar Siswa pada Pembelajaran

Pendidikan Agama Islam

Dari tabel di atas dapat dilihat bahwa:

a. Data pembelajaran pendekatan saintifik memiliki nilai probilitas dengan signifikansinya sebesar 0,070. Angka ini lebih besar dari angka 0,05, berarti untuk variabel pembelajaran pendekatan saintifik, hipotesis nihil yang menyatakan tidak ada perbedaan antara distribusi normal dapat diterima. Hal ini berarti data pembelajaran pendekatan saintifik berdistribusi normal.

b. Data variasi gaya mengajar memiliki nilai probilitas dengan signifikansinya sebesar 0,178. Angka ini jauh lebih besar dari angka 0,05, berarti untuk variabel variasi gaya mengajar, hipotesis nihil yang menyatakan tidak ada perbedaan antara distribusi normal dapat diterima. Hal ini berarti data variasi gaya mengajar berdistribusi normal.

c. Data motivasi belajar siswa memiliki nilai probilitas dengan signifikansinya sebesar 0,060. Angka ini jauh lebih besar dari angka 0,05, berarti untuk variabel motivasi belajar siswa, hipotesis nihil yang menyatakan tidak ada perbedaan antara distribusi normal dapat diterima. Hal ini berarti data motivasi belajar siswa berdistribusi normal.

\section{Uji Linearitas}

Linearitas adalah sifat hubungan yang linear antar variabel, artinya setiap perubahan yang terjadi pada satu variabel akan diikuti perubahan dengan besaran yang sejajar pada variabel lainnya. Dalam penelitian ini, uji linearitas dilakukan dengan aplikasi SPSS dengan menggunakan fungsi compare means. Adapun hasil uji linearitas ditampilkan pada tabel berikut:

Tabel 3. Hasil Uji Linearitas Data

\begin{tabular}{|c|c|c|c|c|}
\hline Data & $\mathrm{F}_{\text {hitung }}$ & $\begin{array}{c}\text { Sig. } \\
\text { (2-tailed) }\end{array}$ & A & Keterangan \\
\hline $\begin{array}{l}\text { Pembelajaran Pendekatan } \\
\text { Saintifik dengan Motivasi } \\
\text { Belajar }\end{array}$ & 28.521 & 0,000 & $<0,05$ & Linear \\
\hline $\begin{array}{l}\text { Variasi Gaya Mengajar } \\
\text { dengan Motivasi Belajar }\end{array}$ & 18.692 & 0,000 & $<0,05$ & Linear \\
\hline
\end{tabular}

Hasil analisis pembelajaran pendekatan saintifik dengan motivasi belajar menunjukkan bahwa sig 0,000 lebih kecil daripada 0,05. Hal ini mengandung arti, terdapat hubungan yang linear antara variabel pembelajaran pendekatan saintifik (X1) dengan motivasi belajar siswa (Y). Kemudian tabel tersebut menunjukkan nilai hasil 
Muhammad Lukman, Risnawati, Nurhasanah Bakhtiar: Pengaruh Pembelajaran Pendekatan Saintifik dan Variasi Gaya Mengajar terhadap Motivasi Belajar Siswa pada Pembelajaran Pendidikan Agama Islam

analisis variasi gaya mengajar dengan motivasi belajar menunjukkan bahwa sig 0,000 lebih kecil daripada 0,05. Hal ini mengandung arti, terdapat hubungan yang linear antara variabel variasi gaya mengajar (X2) dengan motivasi belajar siswa (Y).

\section{Uji Multikolinieritas}

Multikolinieritas berarti adanya hubungan yang kuat antara beberapa atau semua variabel bebas pada model regresi. Jika terdapat multkolineritas maka koofisien regresi menjadi tidak tentu, tingkat kesalahan menjadi sangat besar dan biasanya ditandai dengan nilai koofisien determinasi yang sangat besar tetapi pada pengujian parsial koofisien regresi, tidak ada ataupun kalau ada sangat sedikit sekali koofisien regresi yang signifikan. Pada penelitian ini digunakan nilai variance inflation factors (VIF) sebagi indikator ada tidaknya multikolinearitas diantara variabel bebas.

Tabel 4. Hasil Pengujian Asumsi Multikolinearitas

\begin{tabular}{|c|c|c|c|c|c|c|c|c|}
\hline \multirow{2}{*}{\multicolumn{2}{|c|}{ Model }} & \multicolumn{2}{|c|}{$\begin{array}{l}\text { Unstandardized } \\
\text { Coefficients }\end{array}$} & \multirow{2}{*}{$\begin{array}{c}\text { Standardized } \\
\text { Coefficients }\end{array}$} & \multirow[t]{2}{*}{$\mathrm{t}$} & \multirow[t]{2}{*}{ Sig. } & \multicolumn{2}{|c|}{$\begin{array}{l}\text { Collinearity } \\
\text { Statistics }\end{array}$} \\
\hline & & B & Std. Error & & & & Tolerance & VIF \\
\hline \multirow[t]{3}{*}{1} & (Constant) & 26.239 & 3.826 & & 6.858 & .000 & & \\
\hline & $\begin{array}{l}\text { Pembelajaran } \\
\text { Pendekatan } \\
\text { Saintifik }\end{array}$ & .251 & .067 & .222 & 3.750 & .000 & .794 & 1.260 \\
\hline & $\begin{array}{l}\text { Variasi Gaya } \\
\text { Mengajar }\end{array}$ & .141 & .067 & .125 & 2.109 & .036 & .794 & 1.260 \\
\hline
\end{tabular}

Dari nilai VIF yang dieroleh seperti terlihat pada tabel tersebut menunjukkan tidak ada korelasi yang cukup kuat antar sesama variabel bebas, di mana nilai VIF dari kedua variabel bebas lebih kecil dari 10 dan dapat disimpulkan tidak terdapat multikoloniearitas diantara kedua variabel bebas.

\section{Uji Hipotesis}

Selanjutnya setelah terpenuh uji prasyarat, maka data akan dianalisis secara parametrik, untuk mengetahui apakah terdapat pengaruh pembelajaran dengan pendekatan saintifik dan variasi gaya mengajar terhadap motivasi belajar siswa maka perlu dilakukan pengujian hipotesis secara simultan yang dapat dilihat dari tabel berikut: 
Muhammad Lukman, Risnawati, Nurhasanah Bakhtiar: Pengaruh Pembelajaran Pendekatan Saintifik dan Variasi Gaya Mengajar terhadap Motivasi Belajar Siswa pada Pembelajaran

Tabel 5. Matrik Korelasi Variabel

\begin{tabular}{|c|c|c|c|c|}
\hline & & $\begin{array}{c}\text { Motivasi Belajar } \\
\text { Siswa } \\
\end{array}$ & $\begin{array}{c}\text { Pembelajaran } \\
\text { Pendekatan Saintifik } \\
\end{array}$ & $\begin{array}{c}\text { Variasi Gaya } \\
\text { Mengajar }\end{array}$ \\
\hline \multirow{3}{*}{$\begin{array}{l}\text { Pearson } \\
\text { Corre } \\
\text { lation }\end{array}$} & Motivasi Belajar Siswa & 1.000 & .279 & .226 \\
\hline & $\begin{array}{l}\text { Pembelajaran Pendekatan } \\
\text { Saintifik }\end{array}$ & .279 & 1.000 & .454 \\
\hline & Variasi Gaya Mengajar & .226 & .454 & 1.000 \\
\hline \multirow{3}{*}{$\begin{array}{l}\text { Sig. } \\
(1- \\
\text { tailed })\end{array}$} & Motivasi Belajar Siswa & & .000 & .000 \\
\hline & $\begin{array}{l}\text { Pembelajaran Pendekatan } \\
\text { Saintifik }\end{array}$ & .000 & & .000 \\
\hline & Variasi Gaya Mengajar & .000 & .000 & \\
\hline \multirow[t]{3}{*}{$\mathrm{N}$} & Motivasi Belajar Siswa & 330 & 330 & 330 \\
\hline & $\begin{array}{l}\text { Pembelajaran Pendekatan } \\
\text { Saintifik }\end{array}$ & 330 & 330 & 330 \\
\hline & Variasi Gaya Mengajar & 330 & 330 & 330 \\
\hline
\end{tabular}

Berdasarkan ketentuan di atas, dapat dibuat interpretasi korelasi yang dilihat dari besarnya signifikansi maka dapat diputuskan korelasi sebagai berikut:

a. Terdapat pengaruh signifikan penerapapn pendekatan saintifik terhadap motivasi belajar siswa dengan tingkat pengaruhnya 0,279 dan nilai signifikansinya 0,000 lebih kecil dari 0,05 berarti ada korelasi.

b. Terdapat pengaruh signifikan variasi gaya mengajar terhadap motivasi belajar siswa dengan tingkat pengaruhnya 0,226 dan nilai signifikansinya 0,000 lebih kecil dari 0,05 berarti ada korelasi.

Uji F dilakukan untuk melihat apakah koefisien regresi berganda yang didapat dalam model bisa digunakan untuk memprediksi nilai variabel tak bebas yaitu Y. Hal ini dilakukan apakah variabel bebas secara bersama-sama berpengaruh secara signifikan terhadap nilai variabel terikat. Dari hasil olah data didapat nilai $\mathrm{F}$ hitung seperti pada tabel anova berikut.

Tabel 6. Pengujian F

\begin{tabular}{|c|c|c|c|c|c|c|}
\hline \multicolumn{2}{|c|}{ Model } & \multirow{2}{*}{$\begin{array}{r}\text { Sum of Squares } \\
1777.205\end{array}$} & \multirow{2}{*}{ Df } & Mean Square & \multirow{2}{*}{$\frac{F}{16.186}$} & \multirow{2}{*}{$\frac{\text { Sig. }}{.000^{\mathrm{a}}}$} \\
\hline 1 & Regression & & & 888.603 & & \\
\hline & Residual & 17952.358 & 327 & 54.900 & & \\
\hline & Total & 19729.564 & 329 & & & \\
\hline
\end{tabular}


Muhammad Lukman, Risnawati, Nurhasanah Bakhtiar: Pengaruh Pembelajaran Pendekatan Saintifik dan Variasi Gaya Mengajar terhadap Motivasi Belajar Siswa pada Pembelajaran Pendidikan Agama Islam

Tabel tersebut menjelaskan apakah ada variasi nilai variabel independent dapat menjelaskan nilai dependent dengan menggunakan besar nilainya $\mathrm{F}$. Besar $\mathrm{F}_{\text {hitung }}$ adalah 16,186, sedangkan besar signifikansinya 0,000. Signifikansi tabel Anova 0,000 lebih besar dari 0,05 dengan demikian $\mathrm{Ha}$ diterima $\mathrm{H}_{0}$ ditolak. Dengan demikian, variasi nilai dependent, dengan kata lain variabel pembelajaran pendekatan saintifik danvariasi gaya mengajar dapat memprediksi motivasi belajar siswa.

Untuk menunjukkan persentase semua pengaruh variabel independen terhadap variabel dependen maka dapat dilihat dari tabel di berikut:

Tabel 7. Hasil Uji Koefisien Determinasi (R2)

\begin{tabular}{|c|c|c|c|c|}
\hline Model & $\mathrm{R}$ & R Square & $\begin{array}{l}\text { Adjusted R } \\
\text { Square }\end{array}$ & $\begin{array}{l}\text { Std. Error of } \\
\text { the Estimate }\end{array}$ \\
\hline 1 & $.300^{\mathrm{a}}$ & .090 & .085 & 7.409 \\
\hline
\end{tabular}

Dari tabel tersebut menunjukkan bahwa nilai R Square sebesar 0,090 atau 9\%. Artinya adalah bahwa sumbangan pengaruh variabel pembelajaran pendekatan saintifik (X1) dan variasi gaya mengajar (X2) terhadap motivasi belajar siswa pada mata pelajaran Pendidikan Agama Islam di SMP Negeri Se-Kecamatan Marpoyan Damai Kota Pekanbaru (Y) adalah sebesar 9\%. Sedangkan 91\% dipengaruhi oleh variabel lain yang tidak dimasukkan dalam model penelitian ini.

\section{Simpulan dan Saran}

\section{Simpulan}

Pertama, terdapat pengaruh yang signifikan pembelajaran pendekatan saintifik terhadap motivasi belajar siswa pada mata pelajaran Pendidikan Agama Islam di SMP Negeri se-Kecamatan Marpoyan Damai Kota Pekanbaru dengan tingkat pengaruhnya 0,279 dengan nilai signifikan $0,000<0,05$. Hasil ini menunjukan pembelajaran pendekatan saintifik berperan penting dalam motivasi belajar siswa. Kedua, terdapat pengaruh yang signifikan variasi gaya mengajar terhadap motivasi belajar siswa siswa pada mata pelajaran Pendidikan Agama Islam di SMP Negeri se-Kecamatan Marpoyan Damai Kota Pekanbaru dengan tingkat pengaruhnya 0,226 dengan nilai signifikan 0,000 $<0,05$. Hasil ini menunjukan variasi gaya mengajar berperan penting dalam motivasi belajar siswa. Ketiga, terdapat pengaruh yang signifikan pembelajaran pendekatan 
Muhammad Lukman, Risnawati, Nurhasanah Bakhtiar: Pengaruh Pembelajaran Pendekatan Saintifik dan Variasi Gaya Mengajar terhadap Motivasi Belajar Siswa pada Pembelajaran Pendidikan Agama Islam

saintifik (X1) dan variasi gaya mengajar (X2) terhadap motivasi belajar siswa pada mata pelajaran Pendidikan Agama Islam di SMP Negeri se-Kecamatan Marpoyan Damai Kota Pekanbaru (Y) dengan nilai signifikan 0,000 $<0,05$ dengan nilai R Square sebesar 0,090 atau $9 \%$. Artinya adalah bahwa sumbangan pengaruh pembelajaran pendekatan saintifik (X1) dan variasi gaya mengajar (X2) terhadap motivasi belajar siswa pada mata pelajaran Pendidikan Agama Islam di SMP Negeri se-Kecamatan Marpoyan Damai Kota Pekanbaru (Y) adalah sebesar 9\%. Sedangkan 91\% dipengaruhi oleh variabel lain yang tidak dimasukkan dalam model penelitian ini. Ini berarti terdapat pengaruh yang signifikan pembelajaran pendekatan saintifik dan varaiasi gaya mengajar terhadap motivasi belajar siswa pada mata pelajaran Pendidikan Agama Islam di SMP Negeri seKecamatan Marpoyan Damai Kota Pekanbaru.

\section{Saran}

Dari kesimpulan yang telah diperoleh, maka penulis dapat memberikan saran, adapun saran dapat dijabarkan sebagai berikut: pertama, bagi guru-guru SMP Negeri seKecamatan Marpoyan Damai Kota Pekanbaru, diharapkan memaksimalkan penererapan pendekatan saintifik dan variasi gaya mengajar sehingga lebih baik lagi dan dapat meningkatkan motivasi belajar siswa. Kedua, Bagi siswa SMP Negeri se-Kecamatan Marpoyan Damai Kota Pekanbaru, untuk meningkatkan semangat belajar baik di sekolah maupun di rumah. Dan ketiga, Bagi orang tua, diharapkan dapat memfasilitasi anak dalam belajar agar terpacu semangat belajar dan meraih prestasi terbaik disekolah sehingga bisa membanggakan sekolah dengan berbagai prestasi yang gemilang. Penulis menyadari bahwa tulisan ini masih jauh dari kesempurnaan, untuk itu penulis mengharapkan kritikan dan saran yang membangun guna sempurnanya penulisan ini.

\section{Daftar Pustaka}

Al-'Asqalany, Ibn Hajar. Fath al-Bari fi Shahih al-Bukhary. Juz I. Kairo: Dar al-Hadits, 1998.

Ali, Muhammad. Guru dalam Proses Belajar Mengajar. Bandung: Penerbit Sinar Baru Algensindo, 2010.

Aris, Shoimin. 68 Model Pembelajaran Inovatif dalam Kurikulum 2013. Yogyakarta: Arruz Media, 2014.

Djamarah,Syaiful Bahri. Guru dan Anak Didik dalam Interaksi Edukatif. Jakarta: Rineka Cipta, 2010. 
Muhammad Lukman, Risnawati, Nurhasanah Bakhtiar: Pengaruh Pembelajaran Pendekatan Saintifik dan Variasi Gaya Mengajar terhadap Motivasi Belajar Siswa pada Pembelajaran Pendidikan Agama Islam

Fathurrohman, Muhammad. Paradigma Pembelajaran Kurikulum 2013 Strategi Alternatif Pembelajaran di Era Global. Yogyakarta: Kalimedia, 2015.

Hamalik, Oemar. Psikologi Belajar dan Mengajar. Bandung: Sinar Baru Algensindo 2004.

Kemendikbud, Tim. Bahan Pengembangan Sumber Daya Manusia Pendidikan dan kebudayaan dan Penjaminan Mutu Pendidikan: Bahan Ajar Training of Trainer Implementasi Kurikulum 2013. Jakarta: Kamendikbud, 2013.

Kusumah, Indra. Keajaiban Motivasi: Rahasia Sukses Sang Juara. Bandung: Salamadani, 2011.

Muslimawati, Zulfia, Rosane Medriati, Eko Risdianto. "Penerapan Pendekatan Saintifik Melalui Model Problem Solving untuk Meningkatkan Motivasi Belajar dan Hasil Belajar Fisika di Kelas X IPA.1 SMAN 9 Kota Bengkulu.” Jurnal Pembelajaran Fisika, Vol. 1, No. 1 (2017): 114

Rohani, Ahmad. Pengelolaan Pengajaran. Jakarta: Rineka Cipta, 2010.

Rusman. Pemebelajaran Tematik Terpadu. Jakarta: PT. Raja Grafindo Persada, 2015.

Sadriani, Amram Rede, I Wayan Darmadi. "Pengaruh Pendekatan Saintifik terhadap Motivasi Belajar Sains pada Siswa Kelas IV SD Inpres 1 Sidondo.” Jurnal Kreatif Online, Vol. 6, No. 3 (2018): 163-173

Sani, Ridwan Abdullah. Pembelajaran Saintific untuk Implementasi Kurikulum 2013. Jakarta: PT. Bumi Aksara, 2014.

Sanjaya, Wina. Strategi Pembelajaran: Berorientasi Standar Proses Pendidikan. Jakarta: Kencana Prenada Media, 2010.

Sardiman. Interaksi dan Motivasi Belajar Mengajar. Jakarta: Rajawali Pers, 2016.

Siswati, Vialinda. "Pengaruh Pembelajaran dengan Pendekatan Saintifik terhadap Motivasi dan Prestasi Belajar Mata Pelajaran Pendidikan Agama Islam pada Kelas VII SMP Negeri 1 Wringinanom Gresik." Progressa: Journal of Islamic Religious Instruction, Vol. 1, No. 1 (2017): 1-12

Sugiyono. Metode Penelitian Pendidikan (Pendekatan Kuantitatif, Kualitatif, dan $R \& D)$. Bandung: Alfabeta, 2014.

Sumayasa, I Nyoman, A.A.I.N. Marhaeni, Nyoman Dantes. "Pengaruh Implementasi Pendekatan Saintifik terhadap Motivasi Belajar dan Hasil Belajar Bahasa Indonesia pada Siswa Kelas VI di Sekolah Dasar Se-Gugus VI Kecamatan Abang, Karangasem." e-Journal Program Pascasarjana Universitas Pendidikan Ganesha Program Studi Pendidikan Dasar, Vol. 5 (2015): 1-11

Suryabarata, Sumadi. Psikologi Pendidikan. Jakarta : Raja Grafindo Persada, 2004.

Syadzili, As'ad Furqon, Sukainil Ahzan, Dwi Pangga. "Pengaruh Pendekatan Scientific terhadap Motivasi dan Hasil Belajar Fisika Siswa." Jurnal Ilmiah Pendidikan Fisika Lensa, Vol. 3, No.1 (2015): 244

Uno, Hamzah B. Teori Motivasi dan Pengukurannya. Jakarta: Bumi Aksara, 2016. 